Original Scientific Article

\title{
TIME-DEPENDENT TESTICULAR AND EPIDIDYMAL DAMAGE IN RABBIT BUCKS EXPERIMENTALLY INFECTED WITH TRYPANOSOMA BRUCEI BRUCEI
}

\author{
Adewale Ayodeji Adeyeye ${ }^{1}$, Musbaudeen Olayinka Alayande², Monsurat Bansima Adio², \\ Lauratu Lawal Haliru², Aliyu Abdulrafiu² \\ ${ }^{1}$ Department of Theriogenology and Animal Production, Faculty of Veterinary Medicine, \\ Usmanu Danfodiyo University, Sokoto, Nigeria \\ ${ }^{2}$ Department of Veterinary Parasitology and Entomology, Faculty of Veterinary \\ Medicine, Usmanu Danfodiyo University Sokoto, Sokoto
}

Received 23 October 2020; Received in revised form 9 February 2021; Accepted 18 March 2021

\begin{abstract}
This study was designed to determine the progressive pathological changes in the testis and epididymis of rabbit bucks experimentally infected with Trypanosoma brucei brucei (T. brucei). Fifteen local rabbit bucks were divided into 2 groups comprising 8 bucks in group A and 7 bucks in group B. Bucks in group A were infected intraperitoneally with approximately $1.0 \times 10^{6}$ of $T$. bruce $i$ while bucks in group B served as the uninfected control. The bucks were closely monitored for clinical signs of trypanosomosis from the time of infection till the end of the study. One buck from each group was humanely sacrificed on days 9, 19,29 and 38 post-infection (pi) and its testis and epididymis were examined for pathological changes. At post mortem, no gross lesions were observed in the infected bucks except for adhesion of the testis and epididymis to the scrotum on days 29 and 38 pi. There were no histological changes in the testis and epididymis of the infected buck sacrificed on day 9 pi apart from mild depletion of the epididymal sperm reserve. The buck infected on day 19 pi had moderate testicular degeneration but the epididymis was devoid of sperm reserve. Severe testicular and epididymal degeneration was observed in the buck on days 29 and 38 pi. The testis and epididymis of bucks from the control group were normal with evidence of spermatogenic activities and full epididymal sperm reserve throughout. The study shows that infected bucks were unfit for breeding from day 19 pi.
\end{abstract}

Key words: epididymis, rabbit buck, sperm reserve, testis, Trypanosoma brucei brucei

\section{INTRODUCTION}

Trypanosomosis is a wasting disease of animals that is widespread in tropical areas of Africa and South America (1). It is characterized by anemia, intermittent fever, anorexia, respiratory distress, lacrimation, nasal discharge, edema, enlarged lymph nodes, central nervous system disorders, corneal opacity, reproductive disorders and death in

Corresponding author: Dr. Adewale Ayodeji Adeyeye, $\mathrm{PhD}$

E-mail address: adewale.adeyeye@udusok.edu.ng

Present address: Department of Theriogenology and Animal Production, Faculty of Veterinary Medicine, Usmanu Danfodiyo University,

Sokoto, Nigeria

Phone: +2348032859940

Copyright: (C) 2021 Adeyeye A.A. This is an open-access article published under the terms of the Creative Commons Attribution License which permits unrestricted use, distribution, and reproduction in any medium, provided the original author and source are credited.

Competing Interests: The authors have declared that no competing interests exist.

Available Online First: 19 May 2021

Published on: 15 October 202

https://doi.org/10.2478/macvetrev-2021-0018 severe cases $(2,3,4,5,6,7)$. The disease is caused by blood parasites of the family Trypanosomatidae and genus Trypanosoma (8). The most pathogenic trypanosomes with the widest range of hosts in domestic animals are Trypanosoma brucei, T. congolense and T. vivax (9). Other species are T. evansi, T. equinum, T. equiperdum, T. simiae and Trypanosoma cruzi affecting different species of domestic animals and man $(9,10)$. Trypanosomes are either transmitted biologically (cyclically) by Glossina or mechanically by hematophagous flies (11). There is evidence of transmission via the placenta $(12,13,14)$.

Trypanosoma brucei brucei is the causative agent of African animal trypanosomosis (15). It is a salivarian protozoan belonging to the Trypanozoon sub-genus $(9,15)$. Other members of the sub-genus are T. brucei gambiense that causes human African trypanosomiasis (HAT) 
in West Africa and T. brucei rhodesiense the causative agent of HAT in East Africa (8). T. brucei brucei causes a varying degree of disease associated with the reproductive system among domestic animals. In males, it is characterized by poor quality semen, decreased testosterone level, penile protrusion, preputial inflammation, scrotal dermatitis, loss of libido, increased reaction time, sperm abnormalities, orchitis and severe testicular degeneration $(5,16,17,18,19,20)$. In females, it is manifested by abortion, stillbirths, posterior paresis as well as reproductive and endocrine lesions $(21,22,23,24)$.

Reports on the extent of reproductive damage caused by trypanosomes abound in the literature. However, information as to the period infected males rendered unfit for breeding is lacking. Apart from the studies by Adamu et al. (25) who determined the chronological testicular and epididymal damage in T. vivax infected zebu bulls, no other report is available to the best of our knowledge. However, T. brucei group has a wider host range than other trypanosomes among domestic animals (15). This study was therefore designed to determine the period rabbit bucks infected with $T$. brucei brucei are unfit for breeding.

\section{MATERIAL AND METHODS}

\section{Experimental animals}

Fifteen adult local rabbit bucks with an average weight of $1.29 \mathrm{~kg}$ were acquired from the livestock market in Sokoto metropolis, Nigeria. The bucks were kept in fly-proof pens and fed grower's ration daily as well as spinach and lettuce every other day. Water was provided ad-libitum and they were allowed to acclimatize for three weeks. During this period, they were examined, screened and treated prophylactically for coccidiosis using amprolium 250 WPS

\section{Ethical statement}

The study was carried out following the principles of Laboratory animal care (28). Ethical approval was obtained from the Faculty of Veterinary Medicine, Animal Research Ethics Committee (FAREC), Usmanu Danfodiyo University, Sokoto, Nigeria (No. UDUS/FAREC/2016/AUP-RO/01).

\section{Source of Trypanosome}

The T. brucei brucei isolate used in this study was obtained from the Department of Parasitology and Entomology, Faculty of Veterinary Medicine, Ahmadu Bello University (ABU), Zaria, Kaduna state, Nigeria. About $0.2 \mathrm{ml}$ of blood containing the isolates were inoculated intraperitoneally into albino rats and transported by road from Zaria to Sokoto (about $390 \mathrm{~km}$ ). The parasite was maintained by serial passage of rats until use.

\section{Experimental design}

The bucks were randomly assigned into two groups (A and B). Group A comprised 8 bucks infected with blood containing about $1 \times 10^{6}$ parasite of T. brucei brucei, while group B comprised 7 bucks being the uninfected control. Venipuncture of their ear vein was done daily after the first day of infection to determine the prepatent period as described by Woo (26). The bucks were also observed for clinical signs of trypanosomosis. Parasitemia was estimated daily until patency was established (26). Subsequently, it was determined at 3-4 days interval throughout the study.

\section{Pathology studies}

One rabbit buck was humanely sacrificed from groups A and B on days 9, 19, 29, 38 post-infection (pi). Their testis and epididymis were harvested and grossly examined. The samples were placed in Bouin's solution and processed for histopathological studies. The degree of testicular degeneration was scored as mild, moderate, or severe by examining the level of damage to the germinal epithelial cells of the testis as described by Sekoni et al. (27). The epididymal sperm reserves were estimated by examining a minimum of 50 epididymal tubules at $\times 100$ as described by Adamu et al. (25). The number of tubules with normal sperm reserve out of the total examined number was expressed as a percentage of epididymal sperm reserve.

\section{RESULTS}

The pre-patent period of the infected rabbit bucks ranged from 2 to 3 days with a mean \pm SD of $2.71 \pm 0.49$ days. The infected bucks had rough hair coats, alopecia, pyrexia, mucoid ocular discharge, epistaxis, and progressive anemia. The parasitemia findings are presented in Fig. 1. Parasitemia was first detected on day 2 and peaked to $12.5 \times 10^{5} / \mathrm{ml}$ by day 3 . The second peak of $10.0 \times 10^{5} / \mathrm{ml}$ was on day 6 which gradually decreased and spiked again up to $4.0 \times 10^{5} / \mathrm{ml}$ on day 35 . 


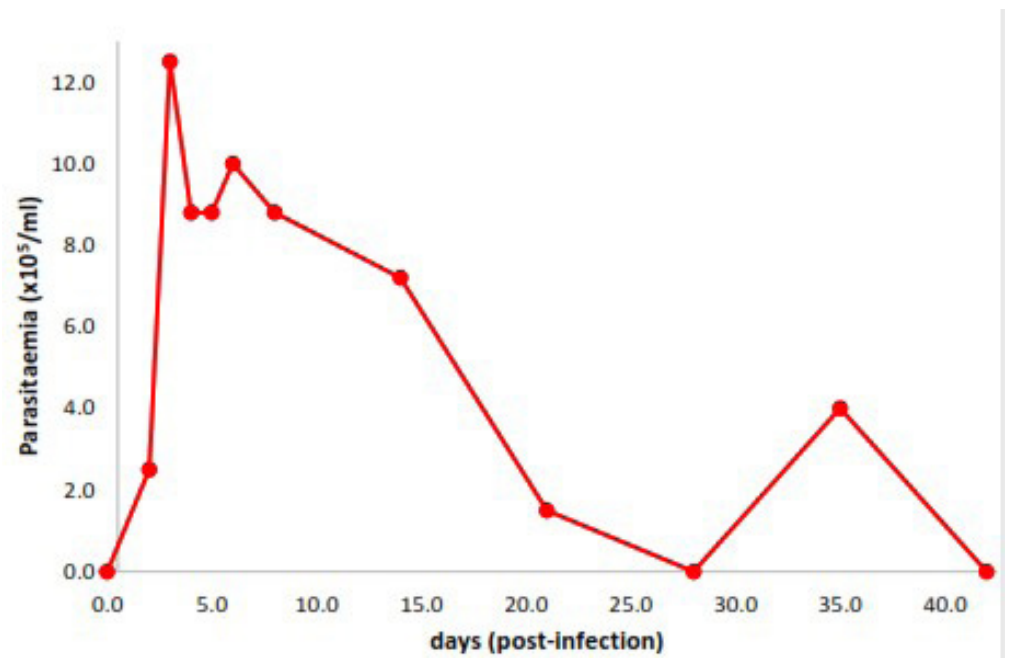

Figure 1. Parasitemia of rabbit bucks experimentally infected with T. brucei brucei

There were no gross lesions seen on the testes and epididymides of infected bucks sacrificed on days 9 and 19. However, infected bucks sacrificed on days 29 and 38 showed adhesion of the testes and epididymides to the scrotum. These lesions were not observed in the control group. The histology of the testis and epididymis of rabbit buck from the control group with evidence of spermatogenic activities in the seminiferous tubules and a full epididymal sperm reserve are given in Fig. 2A and 2B.

The infected buck sacrificed on day 9 had no testicular degeneration. The seminiferous tubules were normal with evidence of spermatogenic activity, although the epididymis had tubules devoid of spermatozoa. The majority (88\%) of the epididymal sperm reserves were filled with spermatozoa (Fig. 3A and 3B; Table 1).
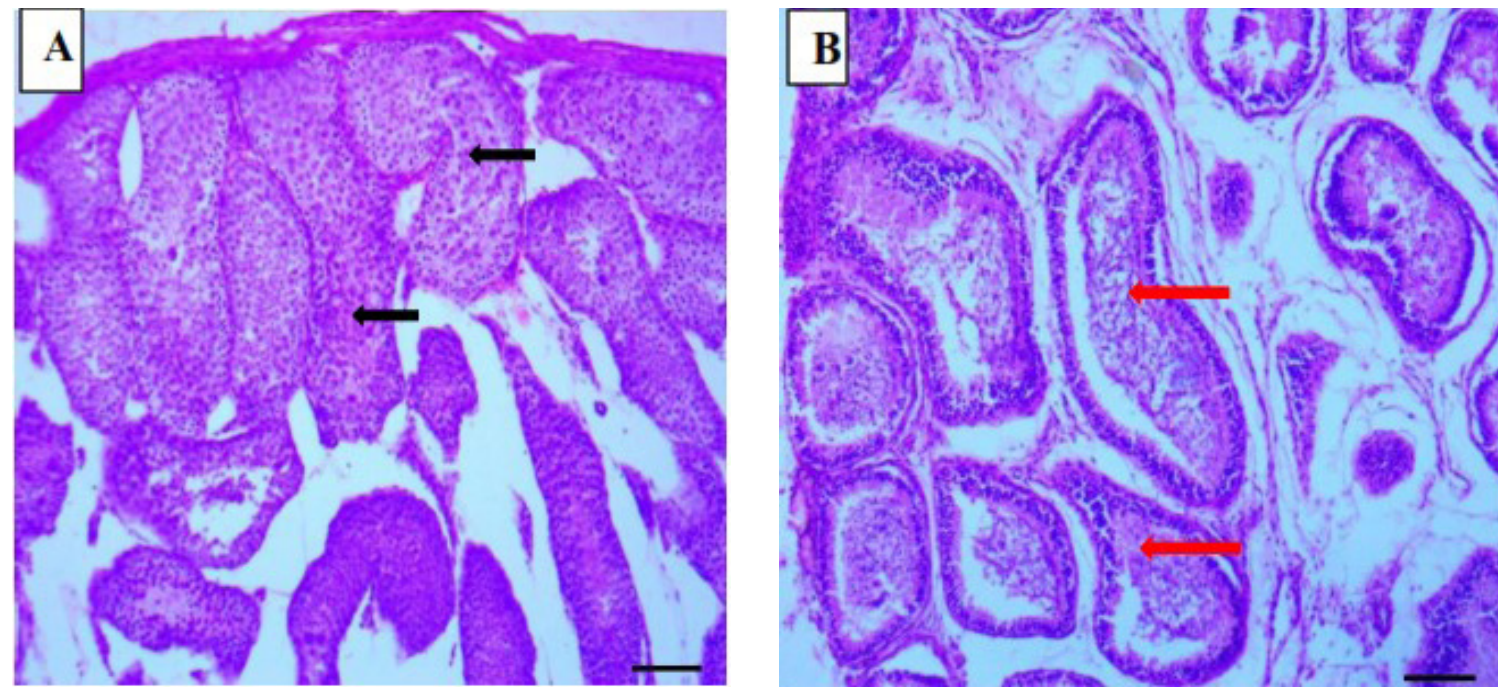

Figure 2. Photomicrograph of rabbit buck (control) showing testis with normal seminiferous tubules and evidence of spermatogenic activity (black arrows) (A); epididymis sperm reserve (red arrows) (B). (H\&E×100; Bar-50 $\mu \mathrm{m})$ 

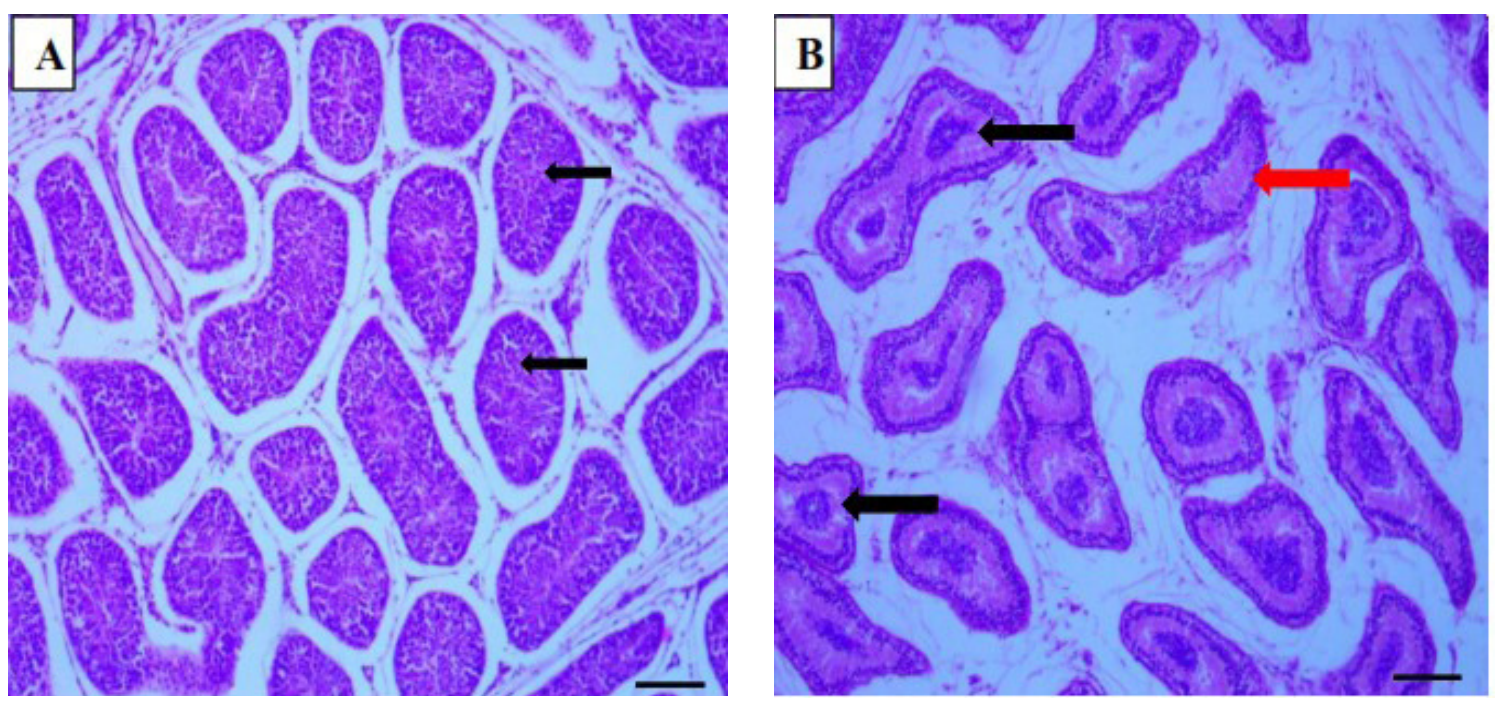

Figure 3. Photomicrograph of rabbit buck at day 9 post $T$. brucei brucei infection showing testis with normal seminiferous tubules and evidence of spermatogenic activity (black arrows) (A) and epididymis with spermatozoa in

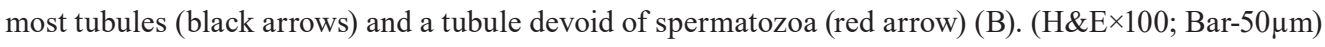

Table 1. Degree of testicular degeneration and epididymal sperm reserve in rabbit bucks experimentally infected with Trypanosoma brucei brucei

\begin{tabular}{lcc}
\hline $\begin{array}{l}\text { Day of sacrifice } \\
(\text { dpi) }\end{array}$ & $\begin{array}{c}\text { Degree of testicular } \\
\text { degeneration }\end{array}$ & $\begin{array}{c}\text { Estimated epididymal } \\
\text { sperm reserve (\%) }\end{array}$ \\
\hline 9 & mild & 88 \\
19 & moderate & 40 \\
29 & severe & 0 \\
38 & severe & 0 \\
\hline
\end{tabular}

dpi - days post infection

In the infected buck sacrificed on day 19, there was moderate testicular degeneration in the testis characterized by atrophied seminiferous tubules and reduced spermatogenic activities. The epididymis was devoid of sperm reserve but contained proteinaceous fluid (Fig. 4A and 4B; Table 1).

The testis of the infected buck sacrificed on day 29 was severely degenerated with the proliferation of fibrous tissue (Fig. 5A), while the epididymal sperm reserve was empty (Table 1). The infected bucks sacrificed on day 38 showed the most severe degeneration with atrophied seminiferous tubules, a severe proliferation of fibrous tissue and cellular infiltration by eosinophilic cells (Fig. 5B). In the epididymis of the same buck, the sperm reserves were empty, devoid of spermatozoa (Table 1). 

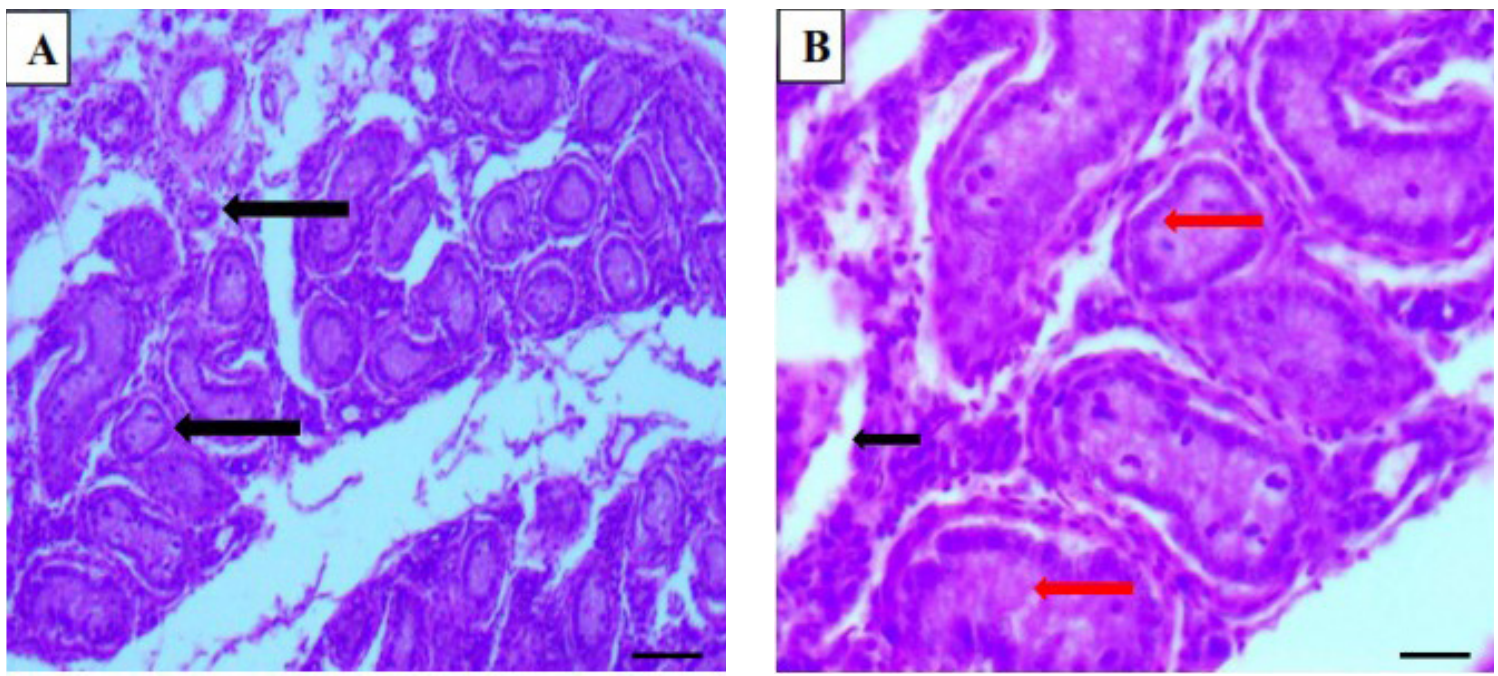

Figure 4. Photomicrograph of rabbit buck at day 19 post $T$. brucei brucei infection showing testis with atrophied seminiferous tubules (black arrows) and reduced spermatogenic activity (A); epididymis devoid of sperm reserve (red arrows) but containing proteinaceous fluid (black arrow) (B). (H\&E $\times 100$; Bar-50 $\mu \mathrm{m})$
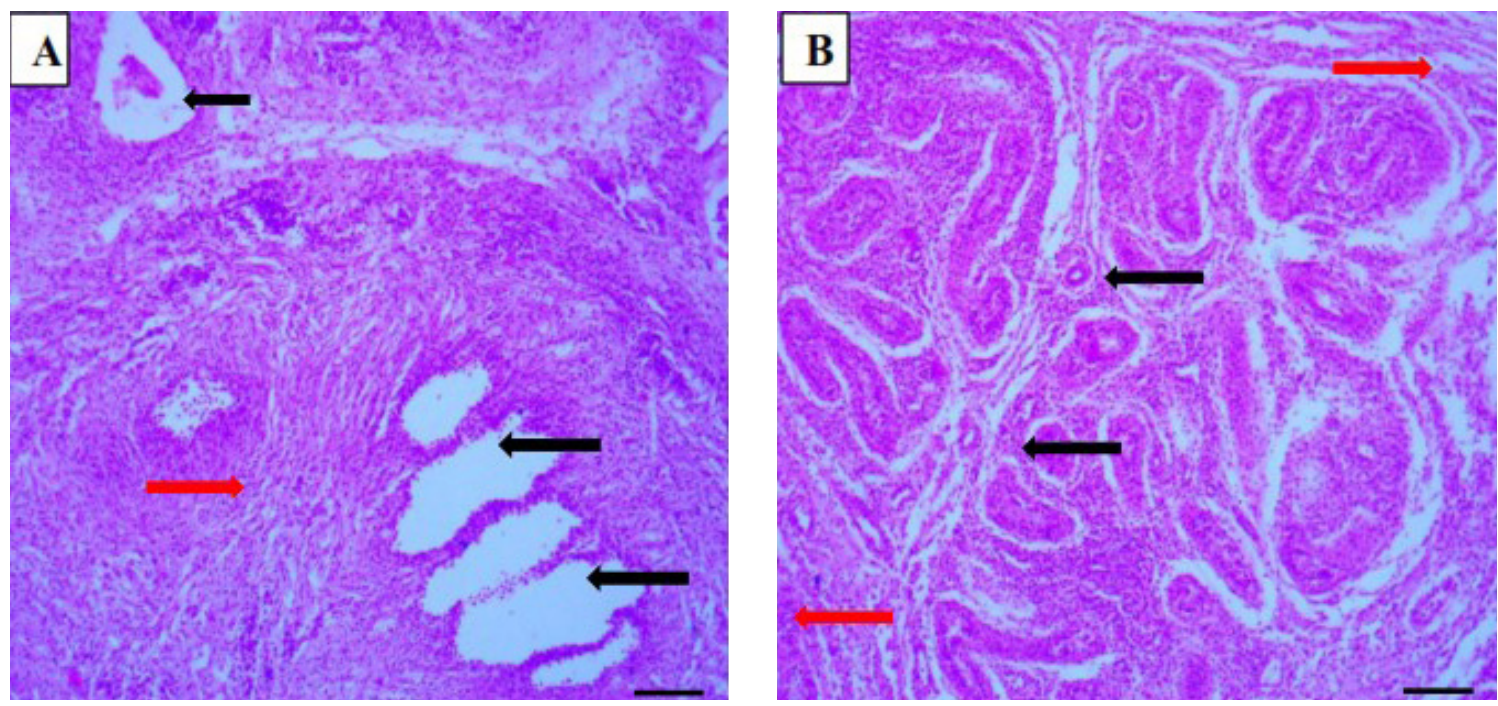

Figure 5. Photomicrograph of the testis of rabbit buck infected with T. brucei brucei 29 days post infection showing marked degeneration (black arrows) and moderate fibrosis (red arrow) (A). 38 days post infection showing atrophied seminiferous tubules, marked degeneration (black arrows) and severe fibrosis (red arrows), and eosinophilic

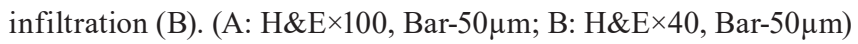

\section{DISCUSSION}

The prepatent period (PP), clinical signs and anemia observed in this study are similar to those observed in our earlier studies in rabbits (5). However, the PP was shorter than $4.70 \pm 0.85$ days reported by Ezema et al. (29) in T. brucei infected crossbred rabbits. This may be associated with the differences in rabbit breed and virulence of the parasite, which is believed to be an important factor in the establishment of trypanosome infection (30). The shorter PP in this present study may suggest that the $T$. brucei isolates used are more virulent thereby increasing its ability to establish infection 
in the bucks. The clinical signs of rough hair coat, alopecia, pyrexia, ocular discharge epistaxis and progressive anemia are consistent with findings in earlier studies of trypanosomosis $(2,3,5,31,32)$.

There were no pathological changes in the testis and epididymis of infected bucks sacrificed on day 9, except for mildly depleted epididymal sperm reserves with an estimated reserve of $88 \%$. The depletion may be caused by decreased blood glucose and subsequent low levels in seminal plasma. Glucose is the major source of energy utilized for motility and maturation by spermatozoa, particularly along the epididymis (33). Trypanosomes have been reported to utilize glucose for their metabolic processes during the peak of parasitemia $(3,34)$. The depletion in the epididymal sperm reserves in this present study occurred 3 days after the second peak of parasitemia. Bucks at this stage may be used for breeding considering the mild degeneration seen on day 9. For the infected buck sacrificed on day 19, there were no gross lesions, although histologically, the seminiferous tubules were atrophied with reduced spermatogenic activities. Also, most of the epididymal sperm reserves were empty but contained proteinaceous fluid. Atrophy of the seminiferous tubules has been reported in T. evansi infected camels (20) and sheep infected with T. brucei (19), and T. vivax (35). Atrophy is the result of progressive testicular degeneration (36), which is caused by intermittent fluctuations in temperature and invasion of the testis by the parasite. The pyrexia may have led to the arrest of the process of spermatogenesis due to increased testicular temperature, resulting in testicular degeneration (10). T. brucei is a tissue invasive parasite capable of causing damage to the testicular parenchyma (37). Also, Carvalho et al. (38) demonstrated severe tissue damage and rupture of epididymal ducts by the parasites in the stroma of the epididymis. This may have enhanced the reduced spermatogenic activity seen on day 19 and the empty epididymal sperm reserves. The presence of proteinaceous fluid in the epididymis may be suggestive of debris of necrotizing sperm cells (25). On day 19, the buck is unfit for breeding even though spermatogenesis has not been completely arrested. The empty epididymis affected by degeneration implies infertility. The sperm maturation, concentration, and transport in the affected epididymis will be compromised (33). However, chemotherapy using antitrypanosomal agents may be effective.
By day 29, degeneration with the proliferation of the fibrous tissue in the testis was observed. The degenerative changes were characterized by necrosis of interstitial cells and destruction of cellular structures within the seminiferous tubules, similarly with the findings of other studies (20, $38,39)$. These changes could be ascribed to the invasive nature of the parasite. At this stage (day 29) the parasite is absent in the blood circulation whereas the genital organs are massively invaded. Moreover, the persistent fluctuation in temperature could be a contributory factor as observed in earlier studies (3). The seminiferous tubules are temperature sensitive and their activities can be altered by minor temperature fluctuations. With the necrosis of the interstitial cells, testosterone production and spermatogenesis are compromised. The proliferation of fibrous tissue suggests the onset of the chronic stage of infection, which often leads to the replacement of normal cells (38). The epididymal sperm reserves were devoid of spermatozoa, expected due to the severe damage of the testicular germinal epithelium that renders the bucks unfit for breeding. There were marked changes in the buck on day 38, similar to those seen on day 29. In addition, there was eosinophilic infiltration of the seminiferous tubules, signifying a break in the blood-testis barrier. The Sertoli cells responsible for this barrier may have been destroyed completely giving rise to the infiltration. Although the hypothalamus and pituitary gland were not monitored in this study, there are possibilities that they may have been affected and contributed to the cessation of spermatogenesis. Studies have demonstrated degenerative processes in these endocrine organs during trypanosome infection $(4,23,38,39)$. This has been observed in camel (20), bulls (27), gazelles (40), boar (41), ram and buck $(7,42)$. Further studies should elucidate the timerelated changes in gonadal tissues of large animals and the use of anti-trypanosome agents in restoring bucks fertility following infection.

\section{CONCLUSION}

The study shows that $T$. brucei brucei causes progressive testicular and epididymal degeneration in infected rabbit bucks leading to infertility by day 19 due to moderate testicular and epididymal damage. After this period, there are severe degenerative changes caused by the parasite on the germinal epithelia of the testis and epididymis. 


\section{CONFLICT OF INTEREST}

The authors declared that they have no potential conflict of interest with respect to the authorship and/or publication of this article.

\section{ACKNOWLEDGEMENTS}

The authors are grateful to Prof. M.S. Abubakar, Department of Veterinary Pathology, Dr. S.M. Sahabi, Department of Morbid Anatomy and Forensic Medicine and Mr. J.M. Imobhio, Department of Veterinary Anatomy, all of Usmanu Danfodiyo University, Sokoto, Nigeria for their technical assistance.

\section{AUTHORS' CONTRIBUTION}

AAA made the conceptualization, designed the methodology and critically reviewed the final draft. MOA was involved in designing the work and supervision. MBA, LLH and AA collected and processed samples, analyzed the data and jointly wrote the first draft. All authors approved the final version for submission.

\section{REFERENCES}

1. Swallow, B.M. (2000). Impacts of trypanosomiasis on African agriculture. [Internet]. Food and agriculture organization of the United Nations. Rome. http:/www.fao.org/3/X4755EN/x4755en.pdf

2. Abubakar, Y.U., Oyedipe, E.O., Eduvie, L.O., Ogwu, D.O., Adeyeye, A.A. (2015). Reproduction and Trypanosoma congolense in Nigerian West African dwarf ewes: I. Effects on the estrous cycle. J Protozool Res. 25(1-2): 1-7.

3. Adeyeye, A.A., Ate, I.U., Lawal, A.I., Adamu, S. (2016). Effects of experimental Trypanosoma evansi infection on pregnancy in Yankasa ewes. Theriogenology 85(5): 862-869.

https://doi.org/10.1016/j.theriogenology.2015.10.034 PMid:26643605

4. Adeyeye, A.A., Ate, I.U., Lawal, A.I., Adamu, S. (2016). Postpartum pathology in Yankasa ewes experimentally infected with Trypanosoma evansi during pregnancy. Comp Clin Pathol. 25(3): 593-598. https://doi.org/10.1007/s00580-016-2236-y

5. Alayande, M.O., Adeyeye, A.A., Abdulrafiu, A, Adio, M.B, Halilu, L.L. (2019). Sexual dimorphism of rabbit bucks and does experimentally infected with Trypanosoma brucei brucei. Veterinaria 68(2): 81-85.
6. Hurtado, O.J., Castro, P.D., Giraldo-Ríos, C. (2016). Reproductive failures associated with Trypanosoma (Duttonella) vivax. Vet Parasitol. 229, 54-59. https://doi.org/10.1016/j.vetpar.2016.09.017 PMid:27809979

7. Okubanjo, O.O., Sekoni, V.O., Ajanusi, O.J., Nok, A.J., Adeyeye, A.A. (2014). Testicular and epididymal pathology in Yankasa rams experimentally infected with Trypanosoma congolense. Asian Pac J Trop Dis. 4(3): 185-189.

https://doi.org/10.1016/S2222-1808(14)60502-8

8. Steverding, D. (2008). The history of African trypanosomiasis. Parasites Vectors 1(1): 1-8. https://doi.org/10.1186/1756-3305-1-3 PMid:18275594 PMCid:PMC2270819

9. Desquesnes, M. (2004). Livestock trypanosomoses and their vectors in Latin America. [Internet]. OIE Paris, France. https://www.oie.int/doc/ged/D9818.PDF

10. Sekoni, V.O. (1994). Reproductive disorders caused by animal trypanosomiases: A review. Theriogenology 42(4): 557-570. https://doi.org/10.1016/0093-691X(94)90373-Q

11. Milligan, P.J.M., Baker, R.D. (1988). A model of tsetse-transmitted animal trypanosomiasis. Parasitology 96(1): 211-239. https://doi.org/10.1017/S0031182000081774 PMid:3362578

12. Argungu, S.Y., Bala, A.Y., Majeed, Q., Usman, M., Umar, A.A. (2015). Possible transplacental transmission of Trypanosoma evansi in experimentally infected albino rats. J Zool Biosci Res. 2(1): 23-27.

13. Ate, I.U., Rekwot, P.I., Nok, A.J., Tekdek, L.B., Luga, I.J. (2006). On-farm transplacental transmission of Trypanosoma vivax in a Bunaji calf in Zaria, Northern Nigeria. Niger Vet J. 27(3): 95-98. https://doi.org/10.4314/nvj.v27i3.3533

14. Kumar, R., Kumar, S., Virmani, N., Yadav, S.C. (2015). Transplacental transmission of Trypanosoma evansi from experimentally infected donkey mare to neonatal foal. J Equine Vet Sci. 35(4): 337-341. https://doi.org/10.1016/j.jevs.2015.02.004

15. OIE. (2013). [Internet]. Trypanosomosis- tsetse transmitted. In: Office of the international epizootic. Terrestrial manual (pp. 1-11). https://www.oie.int/ doc/ged/D9818.PDF

16. Akpavie, S.O., Ikede, B., Egbunike, G.N. (1987). Ejaculate characteristics of sheep infected with Trypanosoma brucei and T. vivax: changes caused by treatment with diminazene aceturate. Res Vet Sci. 42(1): 1-6. https://doi.org/10.1016/S0034-5288(18)30647-7 
17. Ukwueze, C.S., Anene, B.M. (2011). The effects of diabetes mellitus on the pathogenicity of trypanosomosis in rats. JVMAH. 3(3): 40-44.

18. Wada, Y.A., Oniye, S.J., Rekwot, P.I., Okubanjo, O.O. (2016). Single and mixed interaction of experimental Trypanosoma brucei brucei and Trypanosoma evansi on the semen collection reaction time and spermatozoa morphology of Yankasa rams. J Adv Vet Anim Res. 3(4): 360-367.

https://doi.org/10.5455/javar.2016.c174

19. Wada, Y.A., Oniye, S.J., Rekwot, P.I., Okubanjo, O.O. (2016). Testicular pathology, gonadal and epididymal sperm reserves of Yankasa rams infected with experimental Trypanosoma brucei brucei and Trypanosoma evansi. Vet World. 9(7): 759-765. https://doi.org/10.14202/vetworld.2016.759-765 PMid:27536039 PMCid:PMC4983129

20. Amin, Y.A., Noseer, E.A., Fouad, S.S., Ali, R.A., Mahmoud, H.Y. (2020). Changes of reproductive indices of the testis due to Trypanosoma evansi infection in dromedary bulls (Camelus dromedarius): semen picture, hormonal profile, histopathology, oxidative parameters, and hematobiochemical profile. J Adv Vet Anim Res. 7(3): 537-545.

https://doi.org/10.5455/javar.2020.g451

PMid:33005681 PMCid:PMC7521820

21. Allam, L., Ogwu, D., Agbede, R.I., Sackey, A.K. (2012). Posterior paresis in pregnant gilts experimentally infected with Trypanosoma brucei. JVMAH. 4(3): 27-35.

22. Allam, L., Ogwu, D., Agbede, R.I., Sackey, A.K. (2014). Abortion and its probable cause in gilts experimentally infected with Trypanosoma brucei. J Protozool Res. 24, 26-32.

23. Leigh, O.O., Emikpe, B.O., Ogunsola, J.O. (2015). Histopathological changes in some reproductive and endocrine organs of Trypanosoma brucei infected West African dwarf goat does. Bulg J Vet Med. 18(1): 31-39.

https://doi.org/10.15547/bjvm.831

24. Leigh, O.O., Fayemi, O.E. (2013). The effect of experimental Trypanosoma brucei infection on hormonal changes during the oestrous cycle, pregnancy and pregnancy outcome in West Africa Dwarf does. WJAS. 5, 685-695.

25. Adamu, S., Fatihu, M.Y., Useh, N.M., Mamman, M., Sekoni, V.O., Esievo, K.A. (2007). Sequential testicular and epididymal damage in Zebu bulls experimentally infected with Trypanosoma vivax. Vet Parasitol. 143(1): 29-34.

https://doi.org/10.1016/j.vetpar.2006.07.022 PMid:16935425
26. Woo, P.T.K. (1970). The haematocrit centrifuge technique for the diagnosis of African trypanosomiasis. Acta Trop. 27(4): 384-386.

27. Sekoni, V.O., Njoku, C.O., Kumi-Diaka, J., Saror, D.I. (1990). Pathological changes in male genitalia of cattle infected with Trypanosoma vivax and Trypanosoma congolense. Br Vet J. 146(2): 175-180. https://doi.org/10.1016/0007-1935(90)90011-Q

28. CACC (2020). Guide to the care and use of experimental animals (Volume 1, 2nd ed.) c2020 [cited 2020 June 17].

http://www.ccac.ca/Documents/Standards/Guidelines/Experimental_Animals_Vol1.pdf

29. Ezema, W.S., Omeke, B.C., Eze, J.I., Nwanta, J.A. (2009). Studies on the sexual behaviour, haematology and spermatogenesis of male rabbits infected with Trypanosoma brucei brucei. Comp Clin Path. 18(1): 63-68.

https://doi.org/10.1007/s00580-008-0740-4

30. Batista, J.S., Riet-Correa, F., Teixeira, M.M., Madruga, C.R., Simões, S.D., Maia, T.F. (2007). Trypanosomiasis by Trypanosoma vivax in cattle in the Brazilian semiarid: description of an outbreak and lesions in the nervous system. Vet Parasitol. 143(2): 174-181.

https://doi.org/10.1016/j.vetpar.2006.08.017 PMid:16965857

31. Okpala, M.I., Ezeh, I.O., Obi, C.F., Ochiogu, I.S., Obidike, R.I., Ezeokonkwo, R.C. (2019). Impaired epididymal function in Trypanosoma brucei brucei and Trypanosoma congolense infected and treated albino rats. Comp Clin Path. 28(5): 1-6. https://doi.org/10.1007/s00580-019-02983-2

32. Okubanjo,O.O., Sekoni, V.O.,Ajanusi,O.J.,Adeyeye,A.A. (2015). Effects of experimental Trypanosoma congolense infection on sperm morphology in Yankasa rams. Mac Vet Rev. 38(2): 203-208. https://doi.org/10.14432/j.macvetrev.2015.07.050

33. Hermo, L., Robaire, B. (2002). Epididymal cell types and their functions. In: B. Robaire, B. Hinton (Eds.), The epididymis: from molecules to clinical practice (pp. 81-102). Springer, Boston, MA. https://doi.org/10.1007/978-1-4615-0679-9_5

34. Victor, I., Sackey, A.K., Natala, A.J. (2012). Penile protrusion with hemorrhages and preputial inflammation in pigs experimentally infected with Trypanosoma congolense. J Anim Prod Adv. 2(6): 297-302.

35. Anosa, V.O., Isoun, T.T. (1980). Further observations on the testicular pathology in Trypanosoma vivax infection of sheep and goats. Res Vet Sci. 28(2): 151-160. https://doi.org/10.1016/S0034-5288(18)32738-3 
36. Ikede, B.O., Elhassan, E., Akpavie, S.O. (1988). Reproductive disorders in African trypanosomiasis: A review. Acta Trop. 45(1): 5-10.

37. Silva Pereira, S., Trindade, S., De Niz, M., Figueiredo, L.M. (2019). Tissue tropism in parasitic diseases. Open Biol. 9(5): 190036.

https://doi.org/10.1098/rsob.190036

PMid:31088251 PMCid:PMC6544988

38. Carvalho, T., Trindade, S., Pimenta, S., Santos, A.B., Rijo-Ferreira, F., Figueiredo, L.M. (2018). Trypanosoma brucei triggers a marked immune response in male reproductive organs. PLoS Negl Trop Dis. 12(8): e0006690.

https://doi.org/10.1371/journal.pntd.0006690

PMid:30110342 PMCid:PMC6093638

39. Abubakar, Y.U., Oyedipe, E.O., Eduvie, L.O., Ogwu, D.O., Adeyeye, A.A. (2016). Reproduction and Trypanosoma congolense in Nigerian West African dwarf ewes: II. Genital and endocrine lesions. Afr J Cell Path. 6, 16-20.
40. Mbaya, A.W., Nwosu, C.O., Kumshe, H.A. (2011). Genital lesions in male red fronted gazelles (Gazella rufifrons) experimentally infected with Trypanosoma brucei and the effect of melarsamine hydrochloride (Cymelarsan ${ }^{\circledR}$ ) and diminazene aceturate (Berenil@) in its treatment. Theriogenology 76(4): 721-728.

https://doi.org/10.1016/j.theriogenology.2011.04.004 PMid:21601916

41. Omeke, B.C., Igboeli, G. (2000). Disruption of spermatogenesis in boars sub-clinically infected with Trypanosoma brucei brucei. Anim Reprod Sci. 63(3-4): 197-204.

https://doi.org/10.1016/S0378-4320(00)00172-X

42. Shehu, S.A., Ibrahim, N.D., Esievo, K.A., Mohammed, G. (2006). Pathology of experimental Trypanosoma evansi infection in Savannah Brown Buck. Pak J Biol Sci. 9(3): 522-525. https://doi.org/10.3923/pjbs.2006.522.525 